\title{
The Problem of Capitalism in Irish Catholic Social Thought, 1922-1950
}

Le problème du capitalisme dans la pensée catholique irlandaise, 1922-1950

\section{Aidan Beatty}

\section{OpenEdition}

\section{Journals}

Electronic version

URL: https://journals.openedition.org/etudesirlandaises/11722

DOI: 10.4000/etudesirlandaises. 11722

ISSN: 2259-8863

\section{Publisher}

Presses universitaires de Caen

\section{Printed version}

Date of publication: 30 December 2021

Number of pages: $43-68$

ISBN: 978-2-84133-157-0

ISSN: 0183-973X

\section{Electronic reference}

Aidan Beatty, "The Problem of Capitalism in Irish Catholic Social Thought, 1922-1950", Études irlandaises [Online], 46-2 | 2021, Online since 17 December 2021, connection on 03 November 2022 URL: http://journals.openedition.org/etudesirlandaises/11722 ; DOI: https://doi.org/10.4000/ etudesirlandaises. 11722

\section{(c) (1) (2) (2)}

Creative Commons - Attribution-NonCommercial-ShareAlike 4.0 International - CC BY-NC-SA 4.0

https://creativecommons.org/licenses/by-nc-sa/4.0/ 


\title{
The Problem of Capitalism in Irish Catholic Social Thought, 1922-1950 ${ }^{1}$
}

\begin{abstract}
The Catholic Church in $20^{\text {th }}$-century Ireland was infamously anti-communist. In this paper, I look at the other side of this equation: what did the leading savants of Irish Catholicism think of capitalism? Where anti-communism often goes hand-in-glove with an uncritical support for capitalism, Irish Catholic thinkers were often equally suspicious of both communism and capitalism. And their opposition to both economic ideologies drew on similar rationales; a hostility to anything "foreign", a fear that global culture would destroy traditional Irish culture, anti-materialism, a desire to return to an idealised medieval past, and pervasive antisemitic paranoia.
\end{abstract}

Keywords: capitalism, anti-capitalism, antisemitism, social Catholicism, Jesuits, Spiritans.

Résumé: Il est tristement bien connu que l'Église catholique dans l'Irlande du XXe siècle était anticommuniste. Dans cet article, je regarde l'autre côté de cette équation: que pensaient les principaux savants du catholicisme irlandais du capitalisme? Là où l'anticommunisme va souvent de pair avec un soutien sans réserve au capitalisme, les penseurs catholiques irlandais étaient souvent tout aussi méfiants à l'égard du communisme que du capitalisme. Et leur opposition aux deux idéologies économiques s'appuyait sur des logiques similaires: une hostilité à tout ce qui est "étranger», une peur que la culture mondiale puisse détruire la culture irlandaise traditionnelle, l'anti-matérialisme, un désir de revenir à un passé médiéval idéalisé et une paranoïa antisémite omniprésente.

Mots clés: capitalisme, anticapitalisme, antisémitisme, catholicisme social, jésuites, spiritains.

Satan aims at the concentration of property in the hands of a few, either nominally in those of the State, that is, in those of the party in power, or in those of the money-manipulators. He knows that, given fallen human nature, this will lead to the subordination of men to production of material goods and to the treatment of all those not in power as mere individuals, not as persons. For this he favoured Liberalism or Individualism and now favours the reaction against Individualism - Collectivism and Communism. ${ }^{2}$

1. The research for this essay was partially funded with a Professional Development Grant from the Union of Part-Time Faculty at Wayne State University, Detroit. I presented an initial draft at the Irish Studies seminar at the Newberry Library; my thanks to those present for their constructive criticism.

2. Denis Fahey, The Kingship of Christ and Organized Naturalism, Cork, The Forum Press, 1943, p. 21. 


\section{The spectres haunting Irish Catholicism}

Everyone knows Irish Catholics hate communists. Communism, according to a 1931 issue of The Irish Catholic newspaper, was "the most dreadful evil of our time". The Catholic Truth Society of Ireland (CTSI) believed that the Irish working classes were being "flooded" with communist literature in the early 1920s. In October 1931, a joint pastoral from the Catholic hierarchy was read in every church which claimed communism was on the rise in Ireland - singling out the left-republicans of Saor Éire in particular - and stated that no Catholic could be a communist. ${ }^{3}$ Catholic paranoia about communism crossed over with that of the Irish State, which placed various far-left groups under regular surveillance, notwithstanding those groups' miniscule size. ${ }^{4}$ Even "reformist" leftists had to tread lightly in all this ${ }^{5}$ and Catholic anti-communism had a major impact on acceptable political discourse, as remarked upon in a British Foreign Office report in 1970: "The Church certainly has great influence on opinion and most Irish, educated by the Church, regard even pink Socialism as atheistic dynamite. The Russians and their fellows are the legions of hell" ${ }^{6}$ Communism, like lust, was a sin to be extirpated from $20^{\text {th }}$-century Ireland. ${ }^{7}$ This well-known "strong antagonism to communism" 8 within the Church hierarchy across the $20^{\text {th }}$ century has indeed taken many forms and this Irish variant of McCarthyism has become a standard trope in popular cultural representations of the Irish clergy. ${ }^{9}$

This essay, though, looks at the other side of this equation: what did the savants of Irish Catholicism think of capitalism? ${ }^{10}$ Where anti-communism today usually goes hand-in-glove with an uncritical support for capitalism, Irish Catholic thinkers

3. Maurice Curtis, A Challenge to Democracy: Militant Catholicism in Modern Ireland, Dublin, The History Press Ireland, 2010, p. 46, 104, 106.

4. Diarmaid Ferriter, The Transformation of Ireland, Woodstock, Overlook Press, 2005, p. 414.

5. Niamh Puirséil, The Irish Labour Party, 1922-73, Dublin, University College Dublin Press, 2007, p. 144-146 and passim.

6. National Archives of the United Kingdom, FCO33/124; quoted in Brian Hanley, Scott Millar, The Lost Revolution: The Story of the Official IRA and the Worker's Party, Dublin, Penguin, 2009, p. 236.

7. Diarmaid Ferriter, Occasions of Sin: Sex and Society in Modern Ireland, London, Profile Books, 2009, p. 178.

8. Gerard Madden, "Bishop Michael Browne of Galway and Anti-Communism, 1937-1976”, Saothar: Journal of the Irish Labour History Society, vol. 39, 2014, p. 21. See also Gerard Madden, "Defending the Faith", Jacobin, vol. 21, spring 2016, online: https://jacobinmag.com/2016/05/catholic-churchanticommunism-ireland-red-scare.

9. To give just two relatively recent examples: the thundering anti-communism of Fr. Sheridan (Jim Norton) in Ken Loach's Jimmy's Hall (2014) and a bishop in the sitcom Father Ted voicing the familiar anti-socialist complaint that "You can hardly open a newspaper these days without reading some anti-clerical article, written by some bearded leftie! [...] A spell in the army would do them good!” (“Tentacles of Doom”, Father Ted, Channel Four, Hat Trick Productions, 1996).

10. For an overview of pre-1922 clerical thinking on capitalism, see Patrick Doyle, "Catholic Social Teaching, Capitalism and an Economic Vision for an Independent Ireland, 1917-1924", paper presented at "Labour, Gender, and Class in the Struggle for Irish Independence c.1918-24", Conference, National University of Ireland, Galway, 7 November 2019. 
in the mid- $20^{\text {th }}$ century were often almost equally suspicious of both communism and capitalism. ${ }^{11}$ And their opposition to both economic ideologies drew on similar rationales; a hostility to anything "foreign", a fear that global culture would destroy traditional Irish culture, anti-materialism, a desire to return to an idealised medieval past, and pervasive antisemitic paranoia. Whilst ranging across a broader swathe of Catholic social thought at mid-century, the main focus of the essay is on three priests; the Jesuits Richard Devane and Edward Cahill and Denis Fahey of the Holy Ghost Fathers. ${ }^{12}$ All were prolific writers and taken collectively they provide a relatively representative sample of Irish Catholic intellectual culture. All three were politically well-connected, had positions of intellectual authority as teachers and as prolific writers, and were plugged into international Catholic and hard-right currents. ${ }^{13}$ Fahey, Cahill and Devane were all Dublin-based and all attached to hegemonic institutions within Irish Catholicism.

Moreover, there is a certain synergy between all of these figures, both in the sense that their work cross-pollinated each other and they personally knew each other, as well as in the sense that they had shared understandings of capitalism. The recurring ideas of all three thinkers may have remained partially on the political fringes. But that is precisely what this essay studies; a sometimes inchoate anxiety about capitalism that existed on the fringes of, but never separate from, mainstream Irish Catholicism. These three priests were representative of broader currents in post-1922 Catholic social thought, and the broader intellectual culture in which

11. For the role of Catholicism in the development of Irish capitalism, see Raymond Crotty, Ireland in Crisis: A Study in Capitalist Colonial Undevelopment, Dingle, Brandon, 1986, p. 55.

12. For biographical, intellectual and contextual background on all three, see Thomas J. Morrissey, The Ireland of Edward Cahill SJ, 1868-1941, Dublin, Messenger Publications, 2016; Enda Delaney, "Political Catholicism in Post-War Ireland: The Revd. Denis Fahey and Maria Duce, 1945-54", The Journal of Ecclesiastical History, vol. 52, no. 3, July 2001, p. 487-511; Mary Christine Athans, The Coughlin-Fahey Connection: Father Charles E. Coughlin, Father Denis Fahey, C.S.Sp., and Religious Anti-Semitism in the United States, 1938-1954, New York, P. Lang, 1991, p. 29-31; Patrick Maume, "Denis Fahey", in Dictionary of Irish Biography, Cambridge, Cambridge University Press, 2009; Aidan Beatty, "Where Does the State End and the Church Begin? The Strange Career of Richard S. Devane", Studi Irlandesi: A Journal of Irish Studies, no. 9, 2019, p. 443-464; Martin Walsh, Richard Devane SJ: Social Commentator and Advocate, 1876-1951, Dublin, Messenger Publications, 2019. See also Susannah Riordan, “'Storm and Stress': Richard Devane, Adolescent Psychology and the Politics of Protective Legislation, 1922-1935", in Adolescence in Modern Irish History, Catherine Cox, Susannah Riordan (eds.), London, Palgrave Macmillan, 2015, p. 129-150, which unpacks Devane's sophisticated understanding of social issues as well as his attitudes towards Freudianism (of which he remained unsurprisingly suspicious).

13. Fahey was an active figure on the international far-right, corresponding with the American antisemite and isolationist "Radio Priest" Charles Coughlin and the French-Canadian fascist Adrien Arcand, who praised Fahey's writings and offered to translate them into French. See letter from Adrien Arcand to Denis Fahey, 17 February 1949, Kimmage Manor Archives, Denis Fahey Papers, Box 10, Folder 3; letter from Adrien Arcand to Denis Fahey, 24 March 1949, Kimmage Manor Archives, Denis Fahey Papers, Box 10, Folder 3. For background on Arcand and FrenchCanadian antisemitism, see Pierre Anctil, "Interlude of Hostility: Judeo-Christian Relations in Quebec in the Interwar Period, 1919-39”, in Antisemitism in Canada: History and Interpretation, Alan Davies (ed.), Waterloo, Wilfrid Laurier University Press, 1992, p. 135-165. See also Enda Delaney, "Political Catholicism in Post-War Ireland...", p. 488. 
they operated will be pointed to throughout this essay. The next section will give an overview of their writings on capitalism, with subsequent sections analysing the ideological form and content of their work.

\section{Excessive individualism and uncontrolled seeking for profit}

After Richard Devane died in May 1951, his alma mater, Mungret College in Limerick, printed an obituary in their annual, recalling that he had been "zealous" in his devotion to the "interests" of "the poor and working classes". And the obituary's concluding lines stated that:

In his work as a Priest, he saw life in its most depressing and saddening circumstances. He did not underestimate the power of paganism backed by wealth, yet these things did not cloud his spirits for his heart was on the hills with Christ. ${ }^{14}$

In the later decades of his life, Devane had been relegated in government circles, from being a favoured voice on social issues to an increasingly isolated individual. His involvement in the debacle of the Carrigan Commission in 1930, his associations with Cumann na nGaedheal and his creeping fascism may all have hurt his standing with the Fianna Fáil governments of the 1930s and 1940s. But as his obituary shows, Devane had also developed a certain antipathy towards capitalism or, as it euphemistically termed here: paganism backed by wealth.

One of Devane's first forays into social action was in August 1916, when he spoke at a meeting of the Limerick United Trades and Labour Council:

Citing available figures, Devane highlighted the fact that in Limerick city alone, thirtyeight per cent of the population lived in one- or two-room dwellings, and this was unacceptable. It is hard to tell whether he was showing genuine concern for the ordinary person and admonishing the landlords of these properties, or whether he was espousing the Victorian thinking that people were directly responsible for their own actions, mistakes and living conditions. ${ }^{15}$

The issue of poor wages for female workers was another concern of his, which he condemned as "sweating" and "white slavery". ${ }^{16}$ Martin Walsh assumes, probably correctly, that Devane saw the Wall Street Crash as resulting from "an excess of capitalism over spirituality". He saw the economic crash as "an opportunity for renewal; capitalism had failed and there was a chance to mould a new Ireland with spirituality at its heart". ${ }^{17}$ Particularly animating for Devane was what he saw as

14. Mungret Annual, Limerick, Mungret College, 1952 (emphases added). A copy of this annual is included in Devane's personal papers at the Irish Jesuit Archives.

15. Martin Walsh, Richard Devane SJ..., p. 54. Devane was still a parish priest at this point. He did not enter the Jesuit Order until 1918.

16. Ibid., p. $55,57$.

17. Ibid., p. 94 . 
the machinations of the capitalist culture industry and a concurrent fear of global capitalism, most especially as it pertained to the film industry. In his contribution to the 1943 Irish Cinema Handbook, Devane spoke of "our commercial exploitation by cosmopolitan adventurers" in the film industry. He claimed that Irish cinema owners worked under "oppressive conditions imposed by foreign film renters" who force Irish cinemas to take their products. He called this a "despotic invasion of authority from outside" which "should not be tolerated in a sovereign State", 18 though it is not clear if he was offended by the coercion itself rather than its foreign origins. The global capitalist culture industry was a direct threat to Irish national traditions. He also said that capitalist individualism promoted atomism and an unnatural and antisocial isolation. ${ }^{19}$

Edward Cahill's writings on capitalism had a more conventionally economistic register. In his provocatively titled 1935 pamphlet, Capitalism and Its Alternatives, he identified three models of economic organisation; "the capitalistic system, the communal or collectivist system, and the system in which the individual worker is himself the sole owner of the means of production". All three had their shortcomings, as well as their "own peculiar advantages", though the last one, which he also called a peasant society, would be superior to both capitalism and communism. ${ }^{20}$ The capitalist system, of which Great Britain was the most representative avatar, was inherently unequal and chaotic. ${ }^{21}$ Seeming to be almost channeling various Marxist economic theories, Cahill talks of the inherent instability and insecurity of capitalism and of how concentrated economic wealth can become concentrated political power. Though at the same time, he was careful not to follow his anti-capitalist line of thinking too far; "the capitalistic economic regime is not in itself immoral or unjust. It may be operated in a fair and equitable manner". ${ }^{22}$ The concluding note of this short pamphlet was that Ireland should tread a middle path between communal ownership and individualistic capitalism, embracing the positive parts of both whilst also rejecting their inherent flaws. ${ }^{23}$

Capitalism and Its Alternatives was itself a transcript of an invited talk Cahill had given to the Cork School of Commerce's Economics and Literary Society on 12 October 1935. The following day, at the invitation of the Irish Transport and General Workers' Union, he gave a related talk in Connolly Hall on "The Due Reward of Labour":

18. Richard Devane, "The Film in National Life", in Irish Cinema Handbook, Dublin, Parkside Press, 1943, p. 13-28. This discussion here on Devane draws heavily on Aidan Beatty, "Where Does the State End and the Church Begin?...”, p. 452-453.

19. Richard Devane, The Failure of Individualism: A Documented Essay, Dublin, Browne and Nolan - The Richview Press, 1948, p. 5.

20. Edward Cahill, Capitalism and Its Alternatives, Dublin, Browne and Nolan, n.d. [1935], p. 116; reprinted from The Irish Ecclesiastical Record.

21. Ibid., p. 124.

22. Ibid., p. 130.

23. Ibid., p. 139. 
He spoke of the abuses of capitalism in the $19^{\text {th }}$ century and the improvement that had occurred over the past forty years. This was due, he said, to the rise of the workers' unions, state legislation, and the Catholic Social Movement, which had promoted among all classes a more equitable social outlook. Despite the improvements, conditions were still unsatisfactory. In the most highly industrial countries over 20 million workers were unemployed and some 60 million people suffering dire need even as regards the prime necessaties $[s i c]$ of life. Even where there was sufficient employment, the housing conditions in very many of the industrial countries were shamefully bad, and the wages often insufficient. ${ }^{24}$

An initial attempt by Cahill to expand on the ideas of Capitalism and Its Alternatives with an article in The Irish Ecclesiastical Record was rejected by the Jesuit censors, prompting "a quietly forceful letter of complaint to the provincial" from Cahill. ${ }^{25}$ Cahill's views were often at odds with his superiors within the Jesuit order and his focus here on "the abuses of capitalism" was no different. ${ }^{26}$

Yet, Cahill had a long history of espousing these ideas. Early in his career, when serving as Rector of Mungret College in Limerick, he established a Social Study Club that acted as a forum for discussing contemporary issues. In November 1913, at the height of the Dublin Lockout, debates organised by the Club questioned whether "strikes do more harm than good" and "sympathetic strikes are justifiable". The first motion passed by 22 to 15; the result of the second does not survive, though it appears that Cahill spoke in favour of strike actions. A paper on "Socialism" was presented to the school's literary academy around this time. ${ }^{27}$ Cahill's 1927 work Ireland and the Kingship of Christ stated that a by-product of British rule in Ireland was:

[...] economic liberalism, which opened the door to unbridled capitalism and the consequent exploitation of the working population and the growing power of financiers in the function of government. A further development was the prevailing materialism, the fostering of the craving for pleasure and for wealth, and often a reckless mismanagement, waste and misappropriation of the public funds, that resulted in ruinous taxation or the imposition of severe cutbacks on the people..$^{28}$

24. Thomas J. Morrissey, The Ireland of Edward Cahill SJ, 1868-1941, p. 136.

25. Ibid., p. 136-137. For Cahill's account of the censoring the article, see also: letter from Edward Cahill to the Father Provincial, 16 May 1934, Irish Jesuit Archives (IJA), Papers of Fr. Edward Cahill, J55/77(1). That his article was published in The Irish Ecclesiastical Record, suggests that he eventually received permission for this. Though the two-year gap between the lecture and its publications highlights the disagreement over publishing it. For contemporary accounts of these two lectures, see “Capitalism: Jesuit Father's Lecture in Cork", undated press cutting, IJA, Papers of Fr. Edward Cahill, J55/8 (1-2); “Capitalism and Its Alternatives: Lecture by Rev. E. Cahill, S.J.”, undated press cutting, IJA, Papers of Fr. Edward Cahill, J55/8 (3).

26. See, for example, the discussion of Cahill's views in: letter from Nicholas J. Tomkin to Fr. Patrick Bartley, 1 February 1929, IJA, Papers of Fr. Edward Cahill, J55/76, Part 1 of 2.

27. Thomas J. Morrissey, The Ireland of Edward Cahill SJ, 1868-1941, p. 35-36.

28. Ibid., p. 76 . 
In the same pamphlet, initially presented as a talk at the Maynooth Union, Cahill spoke of a "general abandonment of Christian principles in social and civil life" which had created "the moral decadence" as well as "the material misery and unrest of the present day", arguing that the current Pope, Pius XI, held to this view also, along with his three predecessors, Leo XIII (r. 1878-1903), Pius X (19031914), and Benedict XV (1914-1922). The root cause of this was what Cahill called "Liberalism", which for him did not just function as a synecdoche for capitalism as an economic system but also named the culture that had grown up around it. Thus his critique of liberalism was implicitly a critique of capitalist individualism and selfishness built on the claim that capitalism / liberalism "is essentially opposed to Christianity". ${ }^{29}$ Cahill also enumerated the multitude of evils in liberal capitalist modernity; "isolation and insecurity of the labouring population", extreme poverty, "rapacious usury" and the political dominance of "great financiers". He complained that imperialism - the "great colonial expansion opening up new and almost inexhaustible fields of enterprize [sic] to the energies of the European race" - had done nothing to improve the living conditions of the working class. "Pauperism, insecurity, unrest, moral and material degradation [...] and their intensity in any given country corresponds broadly to the extent that Liberalism and its twin sister, modern capitalism, prevail there." When Cahill called liberalism the "antithesis of Christ's Kingship", this was also a label he was applying to capitalism. ${ }^{30}$

In a 1930 work that described Ireland's Peril, he pointed an accusatory finger at the "un-Christian liberalism" that had came to predominance in an Ireland ruled by Britain and controlled by a Protestant ruling elite; "the framework of the social organism has been largely de-Christianised". ${ }^{31}$ In his 1932 work The Framework of a Christian State - later read and praised by de Valera - Cahill held up the communalism of monasteries as a possible alternative to capitalist private property. ${ }^{32}$ Invoking popular contemporary Irish attitudes, he argued that in a Christian state, land should be "Fairly Well Distributed" so as to fully prevent "the concentration of uncultivated ranches in the hands of wealthy owners, which is one of the worst abuses of the modern land system". ${ }^{33}$ Individualistic liberty, self-interest, and competition were all the fruits of "Economic Liberalism". This "capitalist regime", as Cahill called it, "is not essentially vicious", but the Church "has always been more in favour of a system in which the dominating portion of the workers are owners or part owners of the capital with which they labour". "Individualistic Capitalism is nothing else

29. Edward Cahill, The Framework of a Christian State: An Introduction to Social Science, Dublin, M. H. Gill, 1932, p. 118.

30. Edward Cahill, Ireland and the Kingship of Christ: A Paper Read at the Maynooth Union, 1927, Dublin, O’Brien \& Ards, 1927, p. 3-4.

31. Edward Cahill, Ireland's Peril, Dublin, M. H. Gill, 1930, p. 2.

32. De Valera wrote to Cahill to not only thank him for sending him a copy of The Framework of a Christian State, then recently published, but to also tell him "Is fiú éléigheamh agus a aith-leigheamh" ["It is worth reading and re-reading"] (letter from Eamon de Valera to Edward Cahill, 2 August 1932, IJA, Papers of Fr. Edward Cahill, J55/13).

33. Edward Cahill, The Framework of a Christian State..., p. 57. 
than the unjust and perverted form which the capitalist regime has assumed in modern times." ${ }^{34}$ The "gross injustice" of unemployment is inherent to capitalism. ${ }^{35}$ The restricting of access to the resources of the Earth, and the concomitant claim to unlimited rights of ownership, are also part of the inherent injustices of capitalism. ${ }^{36}$

Always more abstract and less materialist than Cahill or Devane, Fahey saw capitalism as the earthly working out of profoundly anti-Christian forces:

Satan aims at a monetary system, by which human persons will be subordinated to the production of material goods, and the production, distribution and exchange of material goods will be subordinated to the making of money and the growth of power in the hands of the financiers. He [Satan] is pleased that money is employed as an instrument for the elimination of the Divine Plan and for the installation of Naturalism. ${ }^{37}$

Like Cahill, Fahey used "Liberalism" as an expansive code-word for both "Capitalism" and its attendant social evils; "The 'Economic Man' of Liberalism" is a "social atom, everywhere identical with himself, always looking for the maximum of financial profit at the cost of the minimum of effort". ${ }^{38}$ And sounding like a Catholic Polanyi, Fahey saw how, under advanced capitalism, social good was made subordinate to the needs of the market:

Liberalism does not consist merely in withdrawing economics from subordination to politics, but in the further step of withdrawing both politics and economics from subjection to the moral law binding on members of Christ. It may be best described by saying that it consists in erecting a particular section or aspect of human activity, economic or political, into a separate domain having its own autonomous end, completely independent of the final end of man as a member of Christ. ${ }^{39}$

Fahey was particularly perturbed by the workings of the newspaper industry and by the prevalence of usury in modern capitalism, as well as "the unlimited competition, unscrupulous underselling and feverish advertising of the present day". ${ }^{40} \mathrm{He}$ also emphasised the tendency towards extreme wealth inequality inherent to capitalism - "ruthless, unchecked [...] tended towards the concentration of capital in the hands of the relatively few" ${ }^{41}$ - and the instability of capitalist cycles of boom and bust. ${ }^{42}$

34. Edward Cahill, The Framework of a Christian State..., p. 137.

35. Ibid., p. 298.

36. Ibid., p. 306-307. It is not clear how Cahill's claims that capitalism is not inherently "vicious" can be squared with the claims about how inherently unjust it is, other than to observe that Cahill may have had fears of capitalism's impact on Irish society, but simultaneously wished to avoid reaching full-throated anti-capitalist conclusions, for reason of his own inherent conservatism.

37. Denis Fahey, The Kingship of Christ and Organized Naturalism, p. 24-25.

38. Denis Fahey, The Church and Farming, Cork, The Forum Press, 1953, p. 77.

39. Ibid., p. 78.

40. Denis Fahey, The Mystical Body of Christ in the Modern World, Dublin, Browne and Nolan, 1939, p. xiii, 7-8, 16. See also Denis Fahey, Money Manipulation and Social Order, Cork, Browne and Nolan (Maria Regina Series; 5), 1944.

41. Ibid., p. 172-173.

42. Denis Fahey, The Mystical Body of Christ and the Reorganization of Society, Cork, The Forum Press, 1945, p. 430-433. 
In The Mystical Body of Christ in the Modern World, Fahey said that it was the "abuses" of capitalism, "with its excessive individualism and uncontrolled seeking for profit", which fueled the rise of communism. ${ }^{43}$ Linking this claim to Irish nationalist history, Fahey identified The Tragedy of James Connolly as being his support for "Marx's wrong philosophy". Communism was an attempt to profit off of the "suffering and disorder" created by Lockean capitalist individualism. ${ }^{44}$ This was a common motif for all three writers: it was the excesses of capitalism itself that pushed workers towards communism. Cahill, perhaps more forgiving of socialists than Fahey, said that monasticism was "a more real, and genuine type of Idealistic Communism". ${ }^{45}$ Cahill also labelled socialism "a reaction against Capitalism [...] the avowed purpose of Socialists [is] to heal the evils which Capitalism has produced". This, he said, was why socialism was so attractive to workers, who have to suffer under these evils. ${ }^{46}$ Similar to Fahey, though, Cahill saw modern materialist socialism (rather than his ideal of Christian monastic communism) as only offering a false liberation. When Cahill traced the history of social Catholicism - of which he himself was an exponent - he described it as an attempt to refute socialism and communism, whilst also eschewing a qualified sympathy for the concerns of the political Left. ${ }^{47}$ In Richard Devane's survey of European history, The Failure of Individualism, he described Marx and Engels as "two remarkable men". Devane even evinced a certain sympathy for the duo, admitting that "Capitalism was no doubt an evil economic system". Yet he still reached the conclusion that the destruction of private property promised by socialism and communism would be far more evil and would reduce all of society to the level of the oppressed proletariat. ${ }^{48}$

Such qualified praise for Marx and Engels would have been anathema to Denis Fahey who saw fit to (incorrectly) remind his readers that Marx's real name

43. Denis Fahey, The Mystical Body of Christ in the Modern World, p. 164.

44. Denis Fahey, The Tragedy of James Connolly, Cork, The Forum Press (Maria Regina Series; 6), 1947, p. 12, 22.

45. Edward Cahill, The Framework of a Christian State..., p. 159. The Jesuit priest J. E. Canavan said socialism has "an ancient, and even an honourable, ancestry", though he then went on to defend the institution of private property. Catholics, Canavan concludes, should guard against "certain extreme Socialistic theories" but also not fail "to recognise what is true, or at least admissible on Catholic principles, in various forms of Socialism". Essentially, Catholics had to tread between "the evils which frequently arise from private ownership and capitalism" and, on the other hand, the "fact" that "Socialists show themselves so generally the enemies of revealed religion, and particularly of Catholicism" (J. E. Canavan, How Far May a Catholic Agree with Socialists?, Dublin, Catholic Truth Society of Ireland, 1919, p. 1, 16).

46. Edward Cahill, The Framework of a Christian State..., p. 156-157.

47. Edward Cahill, The Catholic Social Movement, Dublin, Irish Messenger, 1931, p. 8-10. This pamphlet is made up of articles published in The Irish Ecclesiastical Record, December 1930 and January 1931.

48. Richard Devane, The Failure of Individualism: A Documented Essay, Dublin, Browne and Nolan The Richview Press, 1948, p. 313. Peter Coffey, despite his view that the right to private property should not be an absolute one, believed that "the Socialist ideal of all-round nationalisation of productive wealth" would be "economically disastrous" (Peter Coffey, Between Capitalism and Socialism: Some Landmarks on the Right Road for the Guidance of Irish Catholics, Dublin, Catholic Truth Society of Ireland, 1919, p. 3). 
was "Mordechai" ${ }^{49}$ as part of a general antisemitic horror regarding Marx and Marxism. Fahey thus saw a Jewish continuity in Bolshevism, "an instrument in the hands of the Jews for the establishment of their future Messianic kingdom". ${ }^{50}$ And indeed, antisemitism was an overt element, perhaps the defining element of Fahey's writings. Antisemitism - more particularly, the claim that capitalism was a uniquely “Jewish" project - also featured in Cahill's economics, an anti-Judaism in which also Devane engaged.

\section{The Irish Catholic myth of judeo-capitalism}

In Capitalism and Its Alternatives, Cahill denounced the idea that a government could surrender power or control "to any outside power" or to "irresponsible individuals or foreign syndicates". He went on to argue that:

[...] it is a well-known fact that under the present system of capitalism and international finance, the financial magnates can so manipulate the industrial machine and commercial organisation that by their arbitrary decree, issued at London or New York or Hamburg, millions of workers all over Europe and America can be deprived of their means of livelihood [...]. The same half-hidden anonymous power controls the press, the international news agencies, the theatre, the cinema, the book market. ${ }^{51}$

49. Denis Fahey, The Tragedy of James Connolly, p. 13. He also made this claim in Denis Fahey, The Rulers of Russia and the Russian Farmers [1948], Hawthorne, OMNI Publications, 1987, p. 1. Fahey also raised issues of Jewishness in discussions of Harold Laski, who he claimed was descended from rabbis, and in his description of James Connolly's disputes in the American socialist movement with "the Jew, [Daniel] De Leon" (Denis Fahey, The Tragedy of James Connolly, p. 12, 44). For perhaps related reasons of antisemitism as a form of anticommunism, Cahill seemed to have believed that Friedrich Engels was also Jewish (in reality, he was raised in a pietist Protestant family) (Edward Cahill, The Framework of a Christian State..., p. 168-169). George Clune, a minor clerical figure, saw fit to point out Trotsky's ethnicity: "a certain Jew, Bronstein - who concealed his identity under the assumed Russian name". Clune said "Kerensky was a Jew" (he was not) and claimed "Masonic secret societies" were also backing the Bolsheviks. Clune also wrongly claimed that Marx and Engels saw Russia as the "likely starting-place for the Revolution". As with the other priests, Clune probably read the Communist Manifesto and then filled the gaps in his knowledge with speculation and prejudice. Clune had read Cahill and quoted his Freemasonry and the AntiChristian Movement, from which he borrowed antisemitic ideas (George Clune, Christian Social Reorganisation, Dublin, Browne and Nolan, 1940, p. 57, 133-134).

50. Denis Fahey, The Rulers of Russia, enlarged edition, Dublin - Waterford, Trader Publishing, 1938, p. 1. The American edition of Rulers of Russia was published by Social Justice Publishing in Royal Oak, Michigan, 1940; which is to say, it was published by the notorious antisemitic "radio priest", Charles Coughlin. Adrien Arcand thought Rulers of Russia was "excellent" (letter from Adrien Arcand to Denis Fahey, 17 February 1949, Kimmage Manor Archives, Denis Fahey Papers, Box 10, Folder 3). He offered to translate it into French and also expressed an interest in distributing it in Quebec. "In this French corner of America, literature on 'the' question is very scare, especially since nothing truly interesting can be printed in post-war kosher France" (letter from Adrien Arcand to Denis Fahey, 24 March 1949, Kimmage Manor Archives, Denis Fahey Papers, Box 10, Folder 3).

51. Edward Cahill, Capitalism and Its Alternatives, p. 137. 
Capitalists were a shadowy international force, as powerful as they were invisible. The antisemitic assumptions encoded within this language easily slipped out. Cahill elsewhere claimed that the "secularist press [...] is mostly controlled by the great Jewish financiers". ${ }^{52} \mathrm{He}$ said that any attempt to create a fully Christian society in Ireland would have to overcome the "very powerful opposing influences" of the "international Judæo-Masonic forces". ${ }^{53}$ In his most monumental work Cahill said that capitalist liberalism was controlled by Kabbalists, amongst other esoteric anti-Christian elements, as part of a war "waged throughout the world against the Church by the Masonic and Jewish sectaries". ${ }^{54}$ Cahill claimed that aside from their role in international finance, Jews also controlled politics and the press and were instrumental to the "revolutionary outbreaks of the century". ${ }^{55}$ Indeed, two of Cahill's essays - "Judaism and Freemasonry" and "Judaeo-Masonic Capitalism" - were ill received by his Jesuit censors. He was accused of relying too much on "the statements of French Catholic anti-semites [sic] and writers like Henry Ford" and a censor wrote that he got "an impression of violent anti-Jewish prejudice" in the essays. The censor reached an ungenerous judgement; Edward Cahill possessed "a highly uncritical mind" and both essays were blocked from publication. ${ }^{56}$

Denis Fahey was an even more full-throated antisemite, quoting approvingly the Protocols of the Elders of Zion. ${ }^{57}$ "Fahey's preoccupation with 'the Jewish Question' affected his entire world view." ${ }^{58}$ One of his last works, published in 1953, claimed Zionism was a plot by "financial Jewry" to gain control of the mineral resources of Palestine. ${ }^{59}$ His 1944 discussion of Money Manipulation and Social Order showed a deft awareness of the power dynamics of finance capitalism:

52. Edward Cahill, "Freemasonry: The Jewish Element in Freemasonry”, The Irish Ecclesiastical Record, vol. 32, January-June 1929, p. 38. Cahill also claimed that the Jews control both "the Capitalistic Press" and "the Socialistic Press" (Edward Cahill, "Freemasonry: Masonic Aims and Methods", The Irish Ecclesiastical Record, vol. 32, January-June 1929, p. 137).

53. Edward Cahill, Ireland and the Kingship of Christ..., p. 8.

54. Edward Cahill, The Framework of a Christian State..., p. 5.

55. Edward Cahill, Freemasonry and the Anti-Christian Movement [1929], $5^{\text {th }}$ ed., Dublin, M. H. Gill, 1959, p. 86.

56. Letter from Nicholas J. Tomkin to Fr. Patrick Bartley, 1 February 1929, IJA, Papers of Fr. Edward Cahill, J55/76, Part 1 of 2.

57. Denis Fahey, The Mystical Body of Christ in the Modern World, p. xix-xx. Other than the Feast of Christ the King, which had been established by Pope Pius Xi in his encyclical Quas Primas in 1925, the only other occasion at Kimmage when Fahey always officiated at the liturgy was Good Friday, when he emphasised praying for "the perfidious Jews" (Mary Christine Athans, The Coughlin-Fahey Connection..., p. 56).

58. Mary Christine Athans, The Coughlin-Fahey Connection..., p. 72.

59. Denis Fahey, The Kingship of Christ and the Conversion of the Jewish Nation, Dublin, Holy Ghost Missionary College - Regina Publications, 1953, p. 132-133. Interestingly, there were almost no discussions of capitalism and its evils in this work, perhaps reflecting its Cold War context. There is evidence to suggest that this work did not actually receive an official episcopal imprimatur (though one from the Bishop of Ferns is printed on it). Archbishop John Charles McQuaid made efforts to prevent it being sold in Dublin because "it would be inopportune" (Mary Christine Athans, The Coughlin-Fahey Connection..., p. 71). 
Finance is meant to be the servant of Politics and Economics. Instead it has come to be the master of both, so that human beings are sacrificed to the production of material goods and the production and distribution of material goods are sacrificed to finance. ${ }^{60}$

And yet his warnings about the manipulators of money getting control over the state was clearly a thinly veiled antisemitism. ${ }^{61}$ Fahey's "Mystical Body of Christ", a central motif in his writings, was generally described in opposition to the "organized naturalistic force" of "the Jewish nation". ${ }^{62}$ In critiquing capitalism and communism, Fahey saw fit to ascribe both to Jewish authors: "the Dutch Jew Ricardo and the German Jew Marx" ${ }^{63}$ and he spoke of how Europe has oscillated between two false (but equally Jewish) economic theories, "the pendulum swinging from the extreme error of Judaeo-Protestant Capitalism to the opposite extreme error of the Judaeo-Masonic Communism of Karl Marx". ${ }^{64}$ In another passage, he mixed classically antisemitic tropes with an understanding that workers are alienated by the capitalist mode of production:

The ordinary man will be a mere individual at the mercy of the political wirepullers and of the Jewish financial forces which, in the last resort, manoeuvre them. Under the capitalist system of mass production, scarcely anybody could impress his personality on any article to the production of which he contributed. Workmen ceased to be really human artisans, in proportion as human production lost its artistic character and became infra-human. ${ }^{65}$

Fahey's critiques of capitalism - sometimes cloaked in a coded antisemitism, sometimes overtly Judeophobic - highlight his debt to writers and propagandists from the international far-right, such as G. M. Coogan, a Chicago-based writer and the author of Money Creators and Lawful Money Lectures, as well as Charles Coughlin and Adrien Arcand. ${ }^{66}$ Fahey's writings were distributed in the United

60. Denis Fahey, Money Manipulation and Social Order, p. 13-14.

61. Ibid., p. 9.

62. Denis Fahey, The Kingship of Christ and Organized Naturalism, p. 54. See also Denis Fahey, The Church and Farming, p. 67, which talks of the "unwavering naturalistic opposition of the Jewish nation" to Christianity.

63. Denis Fahey, The Kingship of Christ and Organized Naturalism, p. 106.

64. Denis Fahey, The Mystical Body of Christ in the Modern World, p. 15. An anonymously written 1933 pamphlet likewise laid the blame for socialism on the "German Jew" and had none of the qualified praise for socialism that other Catholic thinkers entertained (An Irish Priest, A Manual of Catholic Action: Its Nature and Requirements, Dublin, M. H. Gill, 1933, p. 1).

65. Ibid., p. 21.

66. The intellectual debt to Coogan is discussed in Denis Fahey, The Mystical Body of Christ and the Reorganization of Society, p. xiii. Cahill's work also found favour on the far-right. See letter from J. S. Barnes, International Centre for Fascism Studies, to Edward Cahill, 17 January 1928, IJA, Papers of Edward Cahill, J55.126. Barnes said that he had read some of Cahill's articles and found them agreeable, stating that Fascism is "an attempt to apply to modern conditions the old, traditional, catholic $[$ sic $]$ philosophy of the State". 
States by the isolationist organisation We, The Mothers Mobilize for America, Inc., and their magazine Women's Voice. ${ }^{67}$

Devane, always more interested in the sexual over the monetary, saw Jewish influences at work in the importation and sale of contraceptives in Ireland. In a story that he related to the Committee on Evil Literature, a 1926 government commission on censorship of birth control literature, he alleged that a "jew" [sic] had been found selling contraceptives in Ballina, in the west of Ireland; when the Gardaí [police] failed to stop him, the local parish priest held an ad hoc trial and attempted to extract a $£ 100$ fine from him. "The jew paid $£ 10$ and cleared out." ${ }^{68}$ In Ireland, as elsewhere, the accusation that Jews hide behind gentile names is a commonplace and in a 1925 article on "Indecent Literature" - by which he generally meant works promoting birth control - Devane claimed that books by the likes of Marie Stopes were on sale in one particular bookshop in Dublin, "the name of which is in strange conflict with that of the alien who owns it". ${ }^{69}$ Devane's allegation here was a coded accusation that Jews and condoms moved along the same occluded international commodity supply-lines. Peter Hession has shown how Irish antisemitism operated through a vocabulary of hygiene and disease. ${ }^{70}$ Devane's variant of that also added in a Catholic antipathy to contraception and other "immoral appliances" as well as anxieties about supposedly "Jewish" commercial practices and the difficulties of enforcing moral control in larger and more religiously-mixed towns and cities. ${ }^{71}$

Devane's discussion of how a small minority control the media in capitalism was also riddled with obvious antisemitic code words. Education, adolescence, and social control were all interlocking concerns in Devane's writings, wherein a cosmopolitan Jewish capitalist culture industry served as a cipher for all those forces that threatened his vision of Catholic Ireland. Peter Martin's history of Irish censorship regimes places Devane's claims alongside those of the nationalist intellectual Aodh de Blacam, who stated in 1939:

If our schools were handed over to Jews there would be an immediate outcry. No clerical managers would allow a Jew, a non-Christian, even if he were a good man, as many of them are, to control a Catholic school, but this [film] trade is controlled by the very worst of them, and cinema has more to say in the moulding of the imagination and the ideals of the race than the schools have. ${ }^{72}$

67. Letter from V. Waggoner to Denis Fahey, 27 January 1954, Kimmage Manor Archives, Denis Fahey Papers, Box 14.

68. “Rev. R.S. Devane, S.J., examined”, 24 June 1926, National Archives of Ireland, Committee on Evil Literature, JUS 7/2/9.

69. Richard Devane, Indecent Literature: Some Legal Remedies, Dublin, Browne and Nolan, 1925, p. 15, footnote 1. This article was originally published in The Irish Ecclesiastical Record.

70. Peter Hession, “New Jerusalem': Constructing Jewish Space in Ireland”, in Irish Questions and Jewish Questions: Crossovers in Culture, Aidan Beatty, Dan O'Brien (eds.), Syracuse, Syracuse University Press, 2018, p. 31-46, 49-53.

71. Aidan Beatty, "Where Does the State End and the Church Begin?...", p. 443, 445.

72. Peter Martin, Censorship in the Two Irelands, 1922-1939, Dublin, Irish Academic Press, 2006, p. 176-177. 
Denis Fahey likewise identified how "the newspapers are more and more at the beck and call of the financial forces which control the machinery of publicity". ${ }^{73}$ The power of finance, Fahey said, is "largely Jewish" "as everybody knows". ${ }^{74}$

That antisemitism is a vehicle for anxieties about capitalism is well-known; in a famous apocryphal formulation usually ascribed to the German Marxist August Bebel, this is "the socialism of fools". ${ }^{75}$ In his recent expansive overview of A Specter Haunting Europe. The Myth of Judeo-Bolshevism, Paul Hanebrink discusses how antisemitic paranoia about communism and capitalism identified both as Jewish threats to national sovereignty. In the context of newly formed nation-states in East Central Europe, whose sovereignty remained in question, such anxieties were widespread. Judeo-Bolshevism, like the fear of Jewish capitalism, was "a phantasmagoria that crystallized broader sets of political and cultural anxieties". ${ }^{76}$ In a much-cited moment, Adorno and Horkheimer asserted: "[...] the fact that someone is called a Jew acts as a provocation to set about him until he resembles that image". ${ }^{77}$ In other words, those with an anxiety about capitalism, identify the object of their anxieties as being "Jewish" and then proceed to attack capitalism as a Jewish project. ${ }^{78}$

73. Denis Fahey, The Mystical Body of Christ in the Modern World, p. xiii. In a letter to Cahill in 1928, Fahey discussed his views of the alleged Jewish control of the press in Germany, Austria, France, Italy, England and the United States (letters from Denis Fahey to Edward Cahill, 1928, IJA, Papers of Fr. Edward Cahill, J55/123-214). Indeed, in The Framework of the Christian State, Cahill appears to directly reference Fahey: "The great capitalistic Press of the United States, England, Germany and France, is now almost entirely controlled by the great Jewish International financiers. Of the papers not directly owned by Jews, Jewish influence usually pre-dominates in the management. In such cases the editor or art critics or principal foreign correspondents, or all of these, usually are Jews" (Edward Cahill, The Framework of a Christian State..., p. 240-241).

74. Denis Fahey, The Mystical Body of Christ in the Modern World, p. 176.

75. Derek J. Penslar, Shylock's Children: Economics and Jewish Identity in Modern Europe, Berkeley, University of California Press, 2001, p. 250. For the broader history of how Anti-Judaism uses constructed images of "Jews" to investigate political or theological concerns totally unconnected to Jewishness, see David Nirenberg, Anti-Judaism: The Western Tradition, New York, W. W. Norton, 2013; Jeremy Cohen, Living Letters of the Law: Ideas of the Jew in Medieval Christianity, Berkeley, University of California Press, 1999; Miri Rubin, Gentile Tales: The Narrative Assault on Late Medieval Jews, Philadelphia, Yale University Press, 1999.

76. Paul Hanebrink, A Specter Haunting Europe. The Myth of Judeo-Bolshevism, Cambridge, Harvard University Press, 2018, p. 7-8 and passim.

77. Max Horkheimer, Theodor Adorno, Dialectic of Enlightenment: Philosophical Fragments, Gunzelin Schmid Noerr (ed.), Edmund Jephcott (trans.), Stanford, Stanford University Press, 2002, p. 153.

78. The assessment of Frank Felsenstein, in a discussion of $18^{\text {th }}$-century English antisemitism, could easily be adapted to $20^{\text {th }}$-century Ireland: “The Jew of the $\left[20^{\text {th }}\right]$ century imagination threatens to overturn and confound the fabric of the social order by the uneasiness that his being brings, although perhaps he unwittingly mirrors the cracks and tensions already inherent there. He is the perpetual outsider whose unsettling presence serves to define the bounds that separate the native [Irishman] from the alien Other" (Frank Felsenstein, Anti-Semitic Stereotypes: A Paradigm of Otherness in English Popular Culture, 1660-1830, Baltimore, Johns Hopkins University Press, 1995, p. 3). See also Jerry Z. Muller, Capitalism and the Jews, Princeton, Princeton University Press, 2010, p. 15-16. 
This methodological tack is useful for getting at the reasons why antisemitism emerges and re-emerges and the "work" to which anti-Jewish rhetoric can be put. And yet it perhaps leaves a certain chicken-and-egg problem unresolved; which came first, the antisemitism or the anticapitalism (or the anticommunism)? Which one was a vehicle for the other? Devane, Fahey and Cahill clearly disliked certain ways that a capitalist social order operated. While they expressed these political emotions through anti-Jewish rhetoric, such antisemitism was hardly unusual amongst pre-Vatican II Catholic clergy (these three priests certainly did not need capitalism to be antisemitic). Moreover, given how much their antisemitism was implicated in their anti-capitalism (and visa-versa), it is probably not possible to definitively say which of the two (their hatred of Jews or their suspicions of capitalism) was logically anterior or which was a function of the other. Their antisemitism and their trepidation about capitalism was also embedded within some other political anxieties; obsessions about sexual mores, a nostalgic desire for a harmonious social order, and a paranoia about Freemasons. The rest of this essay will investigate these three concerns.

\section{The third most masonic country in the world}

Where Fahey had an outsized obsession with Jews - outsized both in terms of the size of the Jewish community in Ireland and in terms of their role (or lack thereof) in capitalism - Edward Cahill's primary bete noire was Freemasons. ${ }^{79}$ In a book first published in 1929 and with the self-evident title Freemasonry and the AntiChristian Movement, Cahill sketched out what he called "the two basic principles of freemasonry": "indifference in matters of religion, which means absence of all real religion, and a tendency towards cosmopolitanism and internationalism, which would supplant the Christian duty of patriotism and loyalty to the state by some kind of ineffective international humanitarianism". ${ }^{80}$ For Cahill, Freemasons were a secularising and denationalising force, operating through capitalism to execute their "anti-social principles". ${ }^{81}$ The accusations are noticeably similar to those made against Jews.

Indeed, Cahill traced the origins of capitalism's social misery to the actions of "Freemasonry, largely organised by Jewish leaders and reinforced by the powerful aid of international finance" ${ }^{82}$ Cahill saw Judaism and Freemasonry as coterminous. Thus his conspiracy theories about Freemasons' political and economic influence simultaneously drew on standard antisemitic paranoia:

79. Though this could also be a false distinction, since Cahill believed "Masons" and "Jews" were one and the same.

80. Edward Cahill, Freemasonry and the Anti-Christian Movement, p. 6.

81. Ibid., p. 48.

82. Edward Cahill, Ireland and the Kingship of Christ..., p. 3. In the same work he identified the "international Judæo-Masonic forces which are now arrayed against Christianity" (ibid., p. 8). 
We have already shown, and it is generally admitted, that the revolutionary outbreaks of the $19^{\text {th }}$ century, which are here attributed to Jewish influence, were largely the work of Freemasonry. That influential finance is also largely dominated by Freemasonry is also generally admitted. ${ }^{83}$

In The Framework of a Christian State, Cahill collapsed together all his usual suspects - "Liberalism, Freemasonry, Bolshevism, and almost every modern movement that is essentially unchristian and anti-Catholic" ${ }^{84}$ - and blamed them all on Jewish actions. From his reading of "several Masonic documents", Cahill had learnt that "[t]he great capitalistic Press of the United States, England, Germany and France, is now almost entirely controlled by the great Jewish International financiers" ${ }^{85}$ Denis Fahey likewise merged Jews and Masons, seeing the latter as the "secret organized naturalistic force" 86 that complimented the "non-secret" Jews. Fahey called Cahill's Freemasonry and the Anti-Christian Movement "an excellent study" of the subject of "the Jewish power in Freemasonry". ${ }^{87}$

As with their antisemitism, Cahill and Fahey's anti-Masonic visions were closely connected to other major political concerns. For Cahill, the problems engendered by capitalism in Ireland were the result of a British-imposed political order:

[...] the present social system in Ireland is neither Irish nor Catholic. It has come to us from a non-Catholic country, which has been the original home and nursing mother of Liberalism and Freemasonry. It is a mould into which our people have been unwillingly forced under the strong hand of tyranny. ${ }^{88}$

In a quasi-postcolonial register, Cahill came close to arguing that post-1922 Ireland remained economically locked-in-place, controlled by a "Protestant ruling elite". ${ }^{89}$ Ultimately, though, his conclusions are couched in ultra-conservative and nationalistic terms:

Even in the Irish Free State, where the Catholic Irish form more than 92 per cent of the population, the anti-Catholic and anti-Irish forces closely allied with international Freemasonry, are very strongly organised, and are supported by the whole weight of British influence [...]. Most even of the larger commercial and manufacturing organisations, the more important banks, most of the Insurance Companies, the railways, the shipping companies, etc., are controlled by the non-Catholic party, and are managed in non-Catholic or English interests. ${ }^{90}$

83. Edward Cahill, "Freemasonry: The Jewish Element in Freemasonry", p. 46-47.

84. Edward Cahill, The Framework of a Christian State..., p. 144.

85. Ibid., p. 240.

86. Denis Fahey, The Kingship of Christ and Organized Naturalism, p. 54.

87. Denis Fahey, The Kingship of Christ According to the Principles of St. Thomas Aquinas, Dublin, Browne and Nolan, 1931, p. 143.

88. Edward Cahill, Ireland and the Kingship of Christ..., p. 6.

89. Edward Cahill, Ireland's Peril, p. 2. I am taking this phrase from Vivek Chibber, Locked in Place: State-Building and Late Industrialization in India, Princeton, Princeton University Press, 2006.

90. Edward Cahill, Ireland's Peril, p. 3-4. 
Claims that the country was controlled by Freemasons were relatively common in $20^{\text {th }}$-century Ireland, "a constant theme in Irish Catholic writings in the interwar period" as Enda Delaney identified it. Freemason as a political slur merged the accusation of being a Cumann na nGaedheal supporter with being "propertied" and Protestant. ${ }^{91}$ In the 1932 general election, for example, Fianna Fáil issued a pamphlet accusing the then-head of Cumann na nGaedheal, W. T. Cosgrave, of being secretly in league with "the Knights of the Compass and Square and Ring" and of kowtowing to their cosmopolitan Masonic capitalism. ${ }^{92}$ Father John Fahy, a radical priest with early sympathies for socialism who later moved to the far-right, claimed in the 1950s that a "a syndicate of British-Orange-American Freemasons" 93 were buying up the land of Ireland. Masons, he claimed, were "The Agents of Satan":

Ireland is the third most Masonic country in the world. We have a Masonic Lodge for every $26\left(5 \times 5^{1 / 2}=26\right)$ square miles of the national territory and a membership which equals four representatives per square mile. We have a Communist cell in every country in Ireland, and no less than 17 Communist cells in Dublin. There is no objective difference between Masonry and Communism, the objective is the same, that is to make the Gentile the slave of the Jewish nation in a World Republic, from which they hope to banish Jesus Christ. Masonry is only the forerunner and secret form of Communism. ${ }^{94}$

A powerful conviction that the Freemasons were a vast conspiracy that worked for the overthrow of the social order had been part of European ultra-conservatism since at least the French Revolution. ${ }^{95}$ Contemporaneous with Cahill and Fahey,

91. Enda Delaney, "Political Catholicism in Post-War Ireland...”, p. 492. Thomas J. Morrissey places Cahill's anti-Masonic sentiments into the context of lingering hostility to Protestants that were still seen as overly economically dominant in the Free State (Thomas J. Morrissey, The Ireland of Edward Cahill SJ, 1868-1941, p. 86). See also Maurice Curtis, A Challenge to Democracy..., p. 57-58.

92. The Economic History of the Land of Erin, Fianna Fáil Pamphlet, 1932, National Library of Ireland, Librarians Office, LO P111: Item 11. Further discussed in Aidan Beatty, Masculinity and Power in Irish Nationalism, 1884-1938, Basingstoke, Palgrave Macmillan, 2016, p. 153-156.

93. John Fahy, “One Hour's Work”, Lia Fáil, no. 1, August 1958.

94. John Fahy, “The Agents of Satan”, Lia Fáil, no. 9, n.d. John Fahy’s one-time comrade Peader O'Donnell - a socialist republican with connections to international communism and a longstanding figure on the extra-parliamentary left - called Fahy "a fine propagandist" with "a great gift for leadership”, his “occasional incoherence” notwithstanding (Peadar O’Donnell, There Will Be Another Day, Dublin, Dolmen Press, 1963, p. 94-95). For background on Fahy, see Brian S. Murphy, "The Stone of Destiny: Father John Fahy (1894-1969), Lia Fáil and Smallholder Radicalism in Modern Irish Society", in Radical Irish Priests, 1660-1970, Gerard Moran (ed.), Dublin, Four Courts Press, 1998, p. 185-218; Brian S. Murphy, “The Land for the People, the Road for the Bullock': Lia Fáil, the Smallholders Crisis and Public Policy in Ireland, 1957-60”, in Offaly: History and Society, William Nolan, Timothy P. O’Neill (eds.), Dublin, Geography Publications, 1998, p. 855-887; Jim Madden, Fr. John Fahy (1893-1969): Radical Republican and Agrarian Activist, Dublin, The Columba Press, 2012.

95. Adam Zamoyski, Phantom Terror: Political Paranoia and the Creation of the Modern State, New York, Basic Books, 2015, p. 14-20. See also Richard Hofstadter, The Paranoid Style in American Politics [1965], New York, Vintage Books, 2008, p. 11. 
Spanish Falangists had a particular obsession with "Masonry", a term that was used interchangeably with "Marxism”, "Judaism” and Catalan separatism.

For [Spanish] nationalists, the specter of a Judeo-Masonic-Bolshevik conspiracy was so powerful precisely because it effectively demonized both their internal and their external enemies. ${ }^{96}$

Encoded within the word "Freemason" as used in Ireland was a hostility to foreign infiltration, particularly that of English Protestants, a brush with which to tar those that a Marxist would call the comprador class, and an antipathy toward the rich and their social exclusivities. Or as Denis Fahey said, Ireland suffered under abuses directly ascribed to "the Judaeo-Puritan capitalism of England, with its excessive individualism and uncontrolled seeking for profit" ${ }^{97}$ Moreover, this antisemitism, as well as the paranoia about Masonic control, were related to a fear about what foreign capitalism might portend for domestic social harmony.

\section{The mystical body politic of Christ}

In The Framework of a Christian State, Edward Cahill described his preferred mode of ownership, a "Christian Concept of Private Ownership", in which the owner recognises his [Cahill's pronoun] obligations to give charitably. Cahill also made the interesting argument that

Anyone may in case of a clear and pressing need (evidens et urgens necessitas) lawfully disregard another's ownership and appropriate for his own use what he thus clearly and urgently requires. ${ }^{98}$

And he suggested that communal property-ownership should exist alongside this Christian property-ownership;

For the Church has always recognised that private property alone is not sufficient to meet the needs of the masses of the people. There will always be numbers who cannot, or in practice will not, acquire private property sufficient for their security. ${ }^{99}$

Cahill argued that early Christianity promulgated a "new concept of ownership" in which the property owner "is merely a steward in the service of the Supreme Owner Who is God". A truly Christian property-owner only took what he needed for his own personal consumption, leaving the rest for the relief of others. A Christian would forego luxuries and "unnecessary comfort and convenience". ${ }^{100}$ Thus, for

96. Paul Hanebrink, A Specter Haunting Europe..., p. 93-94.

97. Denis Fahey, The Mystical Body of Christ in the Modern World, p. 164.

98. Edward Cahill, The Framework of a Christian State..., p. 40.

99. Ibid., p. 41.

100. Ibid., p. 10. 
Cahill, Christianity (and Christian economics) are in stark contrast to capitalism's absolute right of property-ownership and selfishness.

In the first chapter of his 1943 book The Kingship of Christ and Organized Naturalism, Denis Fahey wrote in two opposing columns to more starkly show the differences between "Our Lord's Programme" and "Satan's Aims". In the former,

The Divine Plan for order calls for wide diffusion of ownership of property, in order to facilitate families in procuring the sufficiency of material goods required for the virtuous life of their members as human persons, and for Unions of owners and workers in Guilds or Corporations, reflecting the solidarity of the Mystical Body in economic organization. ${ }^{101}$

Conversely, Satan's socioeconomic order (described above in the epigram) is a concentration of property in the hands of a small minority, found contemporaneously, he believed, in statist communism and individualistic capitalism. In a society where all citizens received "a sufficiency of material goods", they would be free to devote themselves to "virtuous action" and "an ordered life". ${ }^{102}$

Where the capitalist social order was imagined as chaotic and cruel, Cahill, as well as Devane and Fahey, discursively constructed an opposing vision of a harmonious and ordered non-capitalist society. They presented this idealised social order through specific acts of historical imagination, often focused on a romanticised vision of the European Middle Ages. What they were advocating here was not so much anti-capitalism or non-capitalism, but a return to pre-capitalism. Echoing a common Jesuit nostalgia for the Middle Ages, Cahill claimed that his preferred economic system prevailed in the Middle Ages and was still regnant in contemporary Denmark with a presence also in France, Belgium, Holland and "the newly formed states of central Europe". ${ }^{103}$

In his 1948 book, The Failure of Individualism, Richard Devane surveyed the historical roots of the turmoil he felt was afflicting post-war Europe. Describing the work as a "Handbook of Politics and Economics" for citizens who wish to understand "the present social chaos", he traced this "chaos" back to the postReformation erosion of "the organic structure of society" and the ways in which it was replaced by individualism, atomism and an antisocial and unnatural isolation. He identified three forms of individualism; political individualism, represented by the liberalism of Locke and Rousseau ${ }^{104}$ (though the latter could hardly be called an anti-statist individualist); religious individualism, embodied in the English

101. Denis Fahey, The Kingship of Christ and Organized Naturalism, p. 21.

102. Denis Fahey, The Church and Farming, p. 67.

103. Edward Cahill, Capitalism and Its Alternatives, p. 118.

104. Fahey also had issues with Rousseau, taking aim at the "Rousseauist-Masonic deification of the individual" that he said was part of the "the false foundation of both the Liberalist and the Socialist doctrines" (Denis Fahey, The Kingship of Christ and Organized Naturalism, p. 106). 
Protestantism he believed had destroyed the unity of medieval Catholic Europe; and economic individualism, also known as capitalism. ${ }^{105}$

For Denis Fahey, the harmonious body politic is the earthly form of the mystical body of Christ (see fig. 1). ${ }^{106}$ An ideal society would be perfectly ordered, almost Platonic, with all things and people in their correct place; authority comes down from Christ and all economic concerns are subservient to both Catholic theology and the need for social order and harmony. In a lecture in the summer of 1946, Fahey described that Christian order alongside the capitalist chaos that had replaced it:

The gradual rejection of our divine Lord's plan for order through His mystical body, supernatural and suprarational, has led to disorder in the natural organization of the world. I have frequently expressed that disorder to you by saying that according to right order, the manipulation of money is meant to facilitate the production, distribution and exchange of material goods or real wealth, in view of strengthening the family life of human persons who are potential or actual members of Christ. Instead of that right order, human persons and family life are sacrificed for production, while production and consumption in their turn are sacrificed for money and for power for those who manipulate it. ${ }^{107}$

Fahey was explicit as to when this former, more ordered society existed: in the Middle Ages "men lived the life of the Mystical Body" organising themselves economically through a guild system that fomented social solidarity and supposedly prevented the class-based strife that would later be endemic to capitalism. ${ }^{108}$ For Cahill, "the material misery and unrest of the present day" were a result of "the general abandonment of Christian principles in social and civil life", beginning in the Middle Ages and continuing down to the $20^{\text {th }}$ century. ${ }^{109}$

On one occasion, Cahill did admit that the Medieval Christian social system was "not Perfect" but was merely "Founded on True Principles". ${ }^{110}$ In any case, however perfect it may or may not have been, this harmonious social order was

105. Richard Devane, The Failure of Individualism..., p. xi, 5. Devane drew on an eclectic range of sources for all this; the Anglo-French Catholic intellectual Hilare Belloc, Thomas Hobbes, Voltaire, Montesquieu, the Chinese nationalist leader Sun Yat Sen, the French Catholic intellectual Jacques Maritain, Max Weber, and Nicholas Berdyaev, a Russian philosopher who had moved from Marxism to an Orthodox-inflected Christian existentialism and was duly exiled by the Bolsheviks. Devane also critically referenced Friedrich Hayek and, from the opposite end of the political spectrum, Harold Laski (ibid., p. 12, 88, 112, 140-141, 167, 285). See also Aidan Beatty, "Where Does the State End and the Church Begin?...", p. 455-456.

106. This is presumably the graph of society that Athans refers to when she says that Fahey's habit of beginning lectures with his diagram of world order irked students (Mary Christine Athans, The Coughlin-Fahey Connection..., p. 36).

107. "Lecture on Food", lecture notes, 21 July 1946, Kimmage Manor Archives, Denis Fahey Papers, Box 9, Folder 1, Envelope 1.

108. Denis Fahey, The Kingship of Christ and Organized Naturalism, p. 103-104.

109. Edward Cahill, Ireland and the Kingship of Christ..., p. 3.

110. Edward Cahill, The Framework of a Christian State..., p. 25-26. 


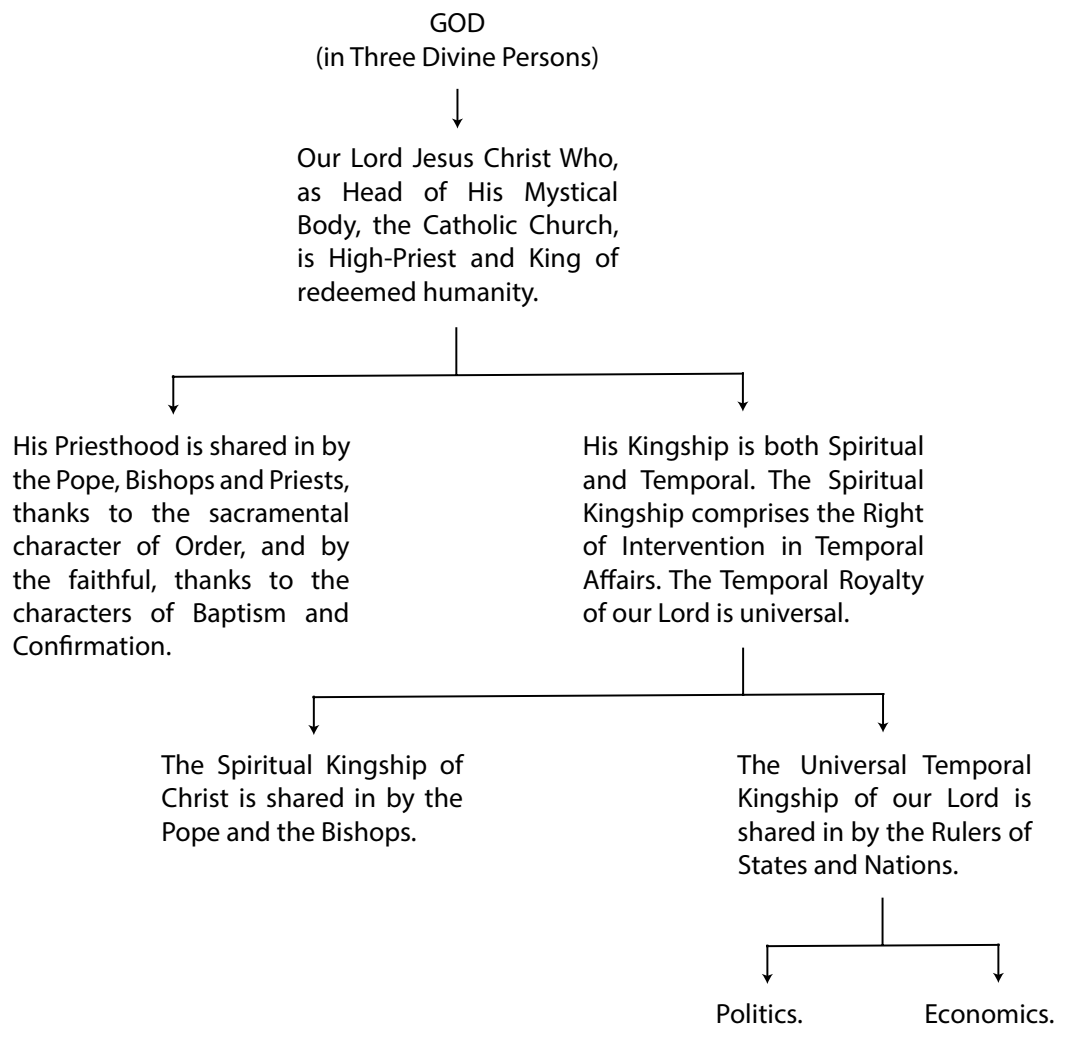

Fig. 1 - "The Divine Plan for Ordered Social Life"

(from Denis Fahey, The Mystical Body of Christ in the Modern World, p. 4)

destroyed by the Reformation. ${ }^{111}$ For Cahill, the "Protestant revolt" ${ }^{112}$ of the $16^{\text {th }}$ century initiated the "decay of European civilization" and a collective slippage into "Rationalism, political and economic Liberalism, Freemasonry, un-christian Capitalism and Socialism". Fahey likewise described the "rending of the Mystical Body of Christ" as coming about as a result of "the so-called Reformation" whilst also blaming the radical liberalism of the French Revolution. ${ }^{113}$

111. Ibid., p. 35-42.

112. Echoing Fahey's language, in a "Prefatory Letter" to The Mystical Body of Christ in the Modern World, Bishop Jeremiah Kinane (from the Diocese of Waterford and Lismore) said that the "principal purpose" of the book was "to deal, from the theological, philosophical and historical standpoint, with the modern revolt against the divine plan for the organization of human society" (Denis Fahey, The Mystical Body of Christ in the Modern World, p. vii).

113. Denis Fahey, The Kingship of Christ and Organized Naturalism, p. 104, 105. Elsewhere, Fahey claimed that "The present economic struggle of Western civilization is largely the outcome of changes which took place, broadly speaking, between 1750 and 1850" (Denis Fahey, The Church and Farming, p. 63). 
There is a certain convenience to all this, as blame for the evils of capitalism can be assigned to two easy Catholic targets - Protestantism and post-1789 secularism - and Catholicism was thus depicted as the religiously-acceptable alternative to both. The antipathy traditionally associated with the two could also be welded to capitalism. Capitalism is evil precisely because of its Protestant ethic.

In addition, valorising the medieval past was a common tactic in Irish nationalist culture. The writings of Patrick Pearse, Dan Breen and Eoin MacNeill are all replete with the idea of a medieval Irish golden age, the obvious inference being that before the Anglo-Norman invasion, before the loss of Irish sovereignty, the country had been in a superior shape. ${ }^{114}$ Likewise, the Gaelic League, one of the most important cultural organisations in late $19^{\text {th }}$ - and early $20^{\text {th }}$-century Ireland, regularly romanticised an image of medieval pre-Anglicisation Ireland. ${ }^{115}$ Devane, Cahill and, to a lesser degree, Fahey, all wrote within this mould, imagining an Ireland that was not Gaelic merely, but non-capitalist as well. As such, it is not a coincidence that Cahill et al. were not just condemnatory of "capitalism" but of English and Protestant capitalism, their economics intersecting with nationalist concerns. And like many other Irish nationalists, they had one other major political concern.

\section{What do priests talk about, when they talk about capitalism?}

The three priests' suspicions of capitalism were never just about capitalism itself; they were always bound with anxieties about sex. For Fahey, the "divine plan" was to have a monetary system implemented that would "facilitate the production and exchange of material goods in view of the virtuous life of Members of Christ in happy families". ${ }^{116}$ The correct purpose of economics was to contribute toward "the organization of family life in view of providing its members with sufficient material resources". ${ }^{117}$ The fundamental danger with capitalism was that it would forcibly damage the heteronormative nuclear family; “The ideas of God, our Lord Jesus Christ, the native land, the family, and the personality of the child, are all being swept away in the name of 'progress,' while the financiers laugh at their poor dupes". ${ }^{118}$ Where "the production of material goods" should serve family life, capitalism had instead brought about a world wherein "family life and human personality" had been made

114. Aidan Beatty, Masculinity and Power in Irish Nationalism, 1884-1938, chap. 2, 5. For works that place this aspect of Irish nationalist culture into a postcolonial frame, see also Elaine Sisson, Pearse's Patriots: St. Enda's and the Cult of Boyhood, Cork, Cork University Press, 2004; Sikata Banerjee, Muscular Nationalism: Gender, Violence, and Empire in India and Ireland, New York, New York University Press, 2012.

115. Aidan Beatty, "The Gaelic League and the Spatial Logics of Irish Nationalism”, Irish Historical Studies, vol. 43, no. 163, 2019, p. 55-72.

116. Denis Fahey, The Kingship of Christ and Organized Naturalism, p. 24.

117. Denis Fahey, The Mystical Body of Christ in the Modern World, p. 7.

118. Ibid., p. 86. Fahey makes this comment - in which "financiers" is code for Jews - in the context of a discussion of communism, showing how, for him, communism and capitalism were tethered together. Both were dangers to his gendered vision of a harmonious social order. 
subordinate "to the production of material goods and the domination of production by money" ${ }^{119}$ As another contemporary priest said, fair wages were necessary because they funded a (male) workers' ability “to marry, support and educate a family, and reasonably develop all his human faculties - physical, mental, moral and religious". ${ }^{120}$ In Cahill's enumeration of the failings of capitalism, he stated that one additional "illustration of the chaos that has come into modern economic life as a result of the abuses of the capitalist regime is the increasing participation of women in industrial and other occupations outside the home, to the neglect of home duties". ${ }^{121}$ As Finola Kennedy has shown, Cahill's attempts to influence de Valera during the drafting of the 1937 Constitution were an expression of his desire to craft a pro-family social policy (and an expression of his antipathy to "Manchester School" capitalism). ${ }^{122}$

Devane's obsessions with sex have already been mentioned and his discussions of the capitalist culture industry were the prime site for this. Films, he said, have the potential to be "a grave national menace to our culture" and he feared that Irish children's nationalist education would be erased by the deracinating effects of commercial movies. "Will their impressionable minds be any more able to resist the seductive lessons of the screen than African primitives armed with bows and arrows can oppose a modern mechanised army with airplanes and tanks?" 123 For Devane, the problem was not so much "sex" itself, but capitalist sex, coded as individualist, pleasure-seeking and commodified, rather than properly procreative and family-oriented. In a preface [Brollach] he wrote for a one-off film magazine published by Craobh na hAiséirghe, a precursor of the short-lived fascist group Ailtirí na hAiséirghe [Architects of the Resurrection], Devane voiced his fears about the denationalising effects of the film industry, "which has all the driving power of limitless capital behind it, appealing to the taste of the ignorant and the half-educated who constitute the great majority of humanity", ${ }^{124}$ thus mixing his idiosyncratic anti-capitalism with old-fashioned social snobbery. There were clearly nationalist concerns at work here, as he pondered:

Can any people preserve for long a distinct national character, a national culture, when these huge organisations, with unlimited resources can break into and take possession of the minds of men everywhere, creating images, sensations, ideas of life which with few exceptions are cheap, vulgar and sensational? ${ }^{125}$

119. Denis Fahey, The Mystical Body of Christ and the Reorganization of Society, p. vii.

120. Peter Coffey, Between Capitalism and Socialism..., p. 7.

121. Edward Cahill, Capitalism and Its Alternatives, p. 134.

122. Finola Kennedy, "Two Priests, the Family and the Irish Constitution", Studies: An Irish Quarterly Review, vol. 87, no. 348, 1998, p. 355. Kennedy goes on to point out that Cahill's contributions have been forgotten, not least because of an uneasiness over his antisemitism and his conspiracy theories of Masonic control.

123. Richard Devane, "Brollach" ["Preface"], in Scannáin [Films], Dublin, Craobh na h-Aiséirghe, 1942 , p. 4.

124. Ibid., p. 3. For the background on Ailtirí na hAiséirghe, see R. M. Douglas, Architects of the Resurrection: Ailtiri na hAiséirghe and the fascist "new order" in Ireland, Manchester, Manchester University Press, 2009; R. M. Douglas, “Not so different after all': Irish and Continental European Antisemitism in Comparative Perspective", in Irish Questions and Jewish Questions..., p. 31-46.

125. Ibid., p. 3-4. 
Devane's description of the culture industry penetrating men's minds has an almost sexual tinge to it and he appears to have feared the fissiparous effects of the global capitalist culture industry on Irish traditions and on sexual mores. Such thinking, as Peter Martin has suggested, often slipped into antisemitic hostility against an international film industry presumed to be controlled by Jews. ${ }^{126}$

Like Devane, Cahill also believed that the sheer volume of capitalist cultural production was a danger; it was not just that it had an immoral content, but that it had a numeric weight to it that could overawe and subdue the supposedly traditional pieties of Irish culture;

The quantity of debasing literature of all kinds sold in Ireland is on the increase. The circulation of Sunday papers is probably over half-a-million. Of these, even the least harmful is unfit for a Catholic country, while very many are positively bad, some being English Sunday papers of the very worst type. ${ }^{127}$

John Henry Whyte has suggested that the intense sexual morality of $20^{\text {th }}$-century Ireland could be understood in economic terms, part of a longer-term post-Famine project of legitimating primogeniture within nuclear families. ${ }^{128}$ The normative procreative family was indeed central to Fahey's very definition of economics:

Economics is the science which studies primarily the personal relations which constitute the family, the relations of husband and wife, parents and children, masters and servants, and then, secondarily, the relations of these persons to external goods (the right of property and the use and acquisition of wealth). Etymologically, economy is the government of the home and of the family. Economics studies families in the constituent relations of their members and then in their conditions of existence. ${ }^{129}$

And George L. Mosse has argued that the $19^{\text {th }}$-century struggle to control sex was part of a larger effort to cope with the ever more obvious results of industrialisation and political upheaval. ${ }^{130}$ This is all echoed in Devane's views: just as capitalism brought dangerous sexual values, so also dangerous sexual values would damage the Irish economy. For instance, Devane believed that young men who stayed up too late at dances, "would be in no fit state to work the land the next morning". ${ }^{131}$ The vision of a self-sufficient nation meant creating a sexually pure culture; that culture, in turn, would strengthen Ireland's autarkic agrarian economy. And connected to all this was his belief that dance halls were recruiting grounds for leftists. ${ }^{132}$ Anticommunism, anti-capitalism and sexual paranoia were all overlapping. Dagmar

126. Peter Martin, Censorship in the Two Irelands, 1922-1939, p. 176.

127. Edward Cahill, Ireland's Peril, p. 20-21.

128. John Henry Whyte, Church and State in Modern Ireland, 1923-1970, Dublin, Gill and Macmillan, 1971, p. 32-33.

129. Denis Fahey, The Mystical Body of Christ in the Modern World, p. 6-7.

130. George L. Mosse, Nationalism and Sexuality: Respectability and Abnormal Sexuality in Modern Europe, New York, H. Fertig, 1985, p. 9.

131. Martin Walsh, Richard Devane SJ..., p. 118.

132. Ibid., p. 122-123. 
Herzog, in her well-known history of sexual mores in post-Nazi Germany has observed that "Christian spokespersons often presented sexual propriety as the cure for the nation's larger moral crisis". ${ }^{133}$ This has led her to the salient point that "sex can be the site for talking about very many other things besides sex and working through a multitude of other social and political conflicts". ${ }^{134}$ In Ireland, though, things seemed to work the other way round. "Capitalism" was a vehicle for talking about the otherwise taboo topic of sex.

\section{Concluding questions}

Life under capitalism is unsettling; it is a world in which "all Chinese walls" are battered down and

All fixed, fast-frozen relations, with their train of ancient and venerable prejudices and opinions, are swept away, all new-formed ones become antiquated before they can ossify. All that is solid melts into air, all that is holy is profaned, and man is at last compelled to face with sober senses his real conditions of life, and his relations with his kind. ${ }^{135}$

More particularly, adding another source of anxiety about the effects of capitalism, there were broad concerns across the Irish political spectrum about the fact that, formal independence notwithstanding, the country continued to be tied economically to Britain. ${ }^{136}$ Thinkers on the Right, as also on the Left, were affected by these realities of life under capitalism; they were often profoundly uneasy about the nature of capitalism. The Right may have drawn on similar anxieties about capitalism as the Left, but thinkers like Denis Fahey or Richard Devane reached radically different conclusions as to why capitalism existed, why it took the form it did, and who was to blame.

This strand of Irish Catholic economic philosophising was part of a larger international current of conservative fears about what capitalism threatens do to the social order. The American paleoconservative Pat Buchanan believes that "[...] the threat comes from atheism, relativism and hard capitalism which, when combined, transform people and nations into an uncontrolled mass of alienated consumers. ${ }^{137}$ All three priests discussed here would almost certainly agree. The views of Fahey

133. Dagmar Herzog, Sex after Fascism: Memory and Morality in Twentieth-Century Germany, Princeton, Princeton University Press, 2005, p. 73.

134. Ibid., p. 8.

135. Karl Marx, Friedrich Engels, The Communist Manifesto [1848], A. J. P. Taylor (ed.), Samuel Moore (trans.), London, Penguin, 1967, p. 83-84.

136. Aidan Beatty, Masculinity and Power in Irish Nationalism, 1884-1938, chap. 6; Aidan Beatty, "The Economic War and the Pamphlet War", in Taxation, Politics and Protest in Ireland, 16622016, Douglas Kanter, Patrick Walsh (eds.), Basingstoke, Palgrave Macmillan, 2019, p. 305-330.

137. Jérôme Jamin, "Cultural Marxism and the Radical Right", in The Post-War Anglo-American Far Right: A Special Relationship to Hate, Paul Jackson, Anton Shekhovtsov (eds.), Basingstoke, Palgrave Macmillan, 2014, p. 98. It is not a coincidence that Buchanan is also prone to anti-Jewish rhetoric. 
are echoed in the work of the Ordre Nouveau, "a group founded in France in the 1930s as an alternative to communism and capitalism, and which had provided an intellectual space for anti-egalitarian, patriarchal, and quasi-mythical ideas". ${ }^{138}$

One of the most curious aspects of these three thinkers' responses to capitalism, though, is the sparseness of their policy suggestions. Fahey had practically nothing to say on this. Cahill's only major plank was to urge a program of popular Catholic social science education and a vaguely defined "social reconstruction". ${ }^{139}$ Devane was, in some ways, more expansive. On the issue of film production and distribution - recurring interests of his - he advocated a fair dose of censorship as well as the establishment of a state-backed National Film Institute, to avoid the baneful influences of foreign commercial cinema. All three thinkers were clearly affected by what they saw as the evils of capitalism and yet their seemingly radical critiques operated within broader conservative ideologies. In his perceptive history of Fianna Fáil, Richard Dunphy has defined that party's economics in the 1920s and 1930s as one of "status quo anti-capitalism", 140 giving a platform to the concerns of the petit-bourgeoisie whilst also managing and massaging these concerns in such a way that they never threatened the underlying property-relations of Irish capitalism. The writings discussed here, do at least suggest that there was indeed a widespread unease about capitalism in post-1922 Ireland, one that a more conventional empirical history would miss. But it is also worth asking if these priests were genuinely anti-capitalist or if they were recognising widespread sentiment and, like Fianna Fáil, hoping to control and re-direct it. Social Catholicism in Ireland, as in other countries, was an attempt to deflate the political Left, whose radicalism shocked the Church. ${ }^{141}$ Lindsey Earner-Byrne has recently made the persuasive argument that post-1922 Irish Catholicism operated according to a "religious bargain" in which a paternalistic hierarchy promised to protect the Catholic poor, who in turn promised their fealty to the Church. ${ }^{142}$ The writings of Cahill, Devane or Fahey could certainly be situated in this conceptual framework; their writings gave voice to the grievances of capitalism's victims, whilst never going too far in their critiques of capitalism.

Aidan BeAtTy

University of Pittsburgh (United States)

138. Alexandra Minna Stern, Proud Boys and the White Ethnostate: How the Alt-Right Is Warping the American Imagination, Boston, Beacon Books, 2019, p. 25.

139. Edward Cahill, Ireland and the Kingship of Christ..., p. 9-14; Edward Cahill, Ireland's Peril, p. 28-29.

140. Richard Dunphy, The Making of Fianna Fáil Power in Ireland, Oxford, Clarendon Press, 1995, p. 39-40. For the receptiveness of Fianna Fáil to social Catholicism and its critiques of capitalism in the 1920s and 1930s, see Mary E. Daly, Industrial Development and Irish National Identity, 1922-1939, Syracuse, Syracuse University Press, 1992, p. 61.

141. Maurice Curtis, A Challenge to Democracy..., p. 14.

142. Lindsey Earner-Byrne, Letters of the Catholic Poor: Poverty in Independent Ireland, 1920-1940, Cambridge, Cambridge University Press, 2017, p. 112. 